\title{
PENGARUH CURRENT RATIO (CR), DEBT TO EQUITY RATIO (DER), NET PROFIT MARGIN (NPM) DAN EARNING PER SHARE (EPS) TERHADAP HARGA SAHAM PERUSAHAAN KONSTRUKSI \& BANGUNAN YANG TERDAFTAR DI BURSA EFEK INDONESIA (BEI) PERIODE 2013-2017
}

\author{
Jenni Suryana \\ Program Studi Magister Manajemen Universitas Tarumanagara \\ jenni.suryana@gmail.com \\ Indra Widjaja \\ Program Studi Magister Manajemen Universitas Tarumanagara
}

\begin{abstract}
This research aims to find out the effects of Current ratio (CR), Debt to equity ratio (DER), Net profit margin (NPM) dan Earning per share (EPS) toward stock price of the construction and building company which is listed in Indonesia Stock Exchange during 20132017.Sampling technique used is purposive sampling with criteria as (1) construction and building company which is listed in Indonesia Stock Exchange over the period from 2013 to 2017; (2) construction and building company who provided financial reports during 20132017; (3) Sample company still operate during research periods from 2013-2017. Based on this criteria, 9 samples were acquired. Data used in this research is secondary data obtained from www.idx.co.id and www.finance.yahoo.com. While the method of analysis used in this research is a method of regression anaylsis of panel data with fixed effect model.The result of this study show that CR and DER don't have significant impact to the stock price of building and construction company; NPM and EPS have a significant price on stock price of building and construction company. Prediction capability of these four variables toward stock price is $92.29 \%$ as indicated by adjusted $\mathrm{R}$ square value, where the rest $7.71 \%$ is affected by others factors which was not entered to this research model.
\end{abstract}

Abstrak : Penelitian ini bertujuan untuk mengetahui pengaruh dari Current ratio (CR), Debt to equity ratio (DER), Net profit margin (NPM) dan Earning per share (EPS) terhadap harga saham perusahaan konstruksi dan bangunan yang terdaftar di Bursa Efek Indonesia periode 2013-2017. Teknik sampling yang digunakan adalah purposive sampling dengan kriteria (1) perusahaan konstruksi dan bangunan yang terdaftar di Bursa Egek Indonesia selama periode 2013-2017; (2) Perusahaan memberikan laporan keuangan selama periode 2013-2017 (3) Perusahaan masih beroperasi selama masa penelitian dari tahun 2013-2017. Berdasarkan kriteria tersebut, diperoleh 9 sampel yang akan digunakan dalam penelitian ini. Data yang digunakan adalah data sekunder yang diperoleh dari www.idx.co.id and www.finance.yahoo.com. Metode yang digunakan dalam penelitian ini adalah metode regresi data panel dengan menggunakan fixed effect model. Hasil penelitian menunjukkan bahwa CR dan DER tidak berpengaruh signifikan terhadap harga saham dari perusahaan bangunan dan konstruksi; NPM dan EPS memiliki pengaruh signifikan terhadap harga saham dari perusahaan bangunan dan konstruksi. Prediksi kemampuan keempat variabel tersebut untuk menjelaskan harga saham adalah sebesar 92,29\% yang diindikasikan olej nilai adjusted R square, dimana sisanya sebesar $7.71 \%$ dipengaruhi oleh factor lainnya yang tidak dijelaskan dalam penelitian ini.

Keywords : Current ratio (CR), Debt to equity ratio (DER), Net profit margin (NPM), Earning per share (EPS),Stock price, panel data, fixed effect model, building and construction. 


\section{A. LATAR BELAKANG}

Investasi merupakan salah satu instrumen pembangunan yang diperlukan oleh suatu bangsa untuk meningkatkan kesejahteraan masyarakatnya, tidak terkecuali Indonesia. Adapun langkah dari pemerintah Indonesia yang saat ini terus melakukan percepatan dalam pembangunan infrastuktur, telah menjadikan Indonesia sebagai sebagai pangsa pasar jasa konstruksi terbesar di ASEAN.

Selain melihat adanya prospek yang menarik dan menjanjikan bagi investor/calon investor untuk menanamkan modalnya di pasar saham bidang konstruksi, tentunya ada hal lain yang harus diteliti oleh pemegang investor/calon investor sebelum memutuskan untuk memananamkan modal di perusahaan tertentu, yaitu bagaimana kondisi suatu perusahaan tersebut, khususnya kondisi keuangan dari perusahaan tersebut. Dalam melakukan penilaian kondisi keuangan perusahaan, investor/calon umumnya akan melakukan analisa terhadap rasio-rasio yang terdapat pada laporan keuangan.

\section{B. TUJUAN PENELITIAN}

Sesuai dengan latar belakang yang dikemukakan di atas, maka tujuan dari penelitian ini adalah sebagai berikut:

1. Untuk mengetahui pengaruh Current Ratio (CR) terhadap harga saham perusahaan konstruksi dan bangunan yang terdaftar di Bursa Efek Indonesia (BEI).

2. Untuk mengetahui pengaruh Debt to Equity Ratio (DER) terhadap harga saham perusahaan konstruksi dan bangunan yang terdaftar di Bursa Efek Indonesia (BEI).

3. Untuk mengetahui pengaruh Net Profit Margin (NPM) terhadap harga saham perusahaan konstruksi dan bangunan yang terdaftar di Bursa Efek Indonesia (BEI).

4. Untuk mengetahui pengaruh Earning Per Share (EPS) terhadap harga saham perusahaan konstruksi dan bangunan yang terdaftar di Bursa Efek Indonesia (BEI).

5. Untuk mengetahui pengaruh Current Ratio (CR), Debt to Equity Ratio (DER), Net Profit Margin (NPM), Earning Per Share (EPS) secara bersama-sama terhadap harga saham perusahaan konstruksi dan bangunan yang terdaftar di Bursa Efek Indonesia (BEI).

\section{TINJAUAN PUSTAKA}

Current ratio (CR) merupakan rasio yang digunakan untuk mengukur perbandingan antara asset lancar dengan kewajiban lancar. Current ratio (CR) merupakan bagian dari rasio likuiditas yang berguna untuk menunjukkan sejauh mana kemampuan perusahaan dalam memenuhi (membayar) kewajiban lancar (jangka pendek) menggunakan asset lancar. Hasil penelitian oleh Putri \& Soekotjo (2017) menunjukkan bahwa CR mempunyai pengaruh yang signifikan terhadap pertimbangan investor dalam menentukan harga saham. Penelitian yang dilakukan oleh Amanah et al (2014) juga menyatakan Current Ratio berpengaruh signifikan terhadap harga saham.

Debt to equity ratio (DER) merupakan rasio yang paling sering digunakan dalam analisis fundamental. Debt to equity ratio (DER) menunjukkan sejauh mana perusahaan dapat mengcover kewajiban menggunakan modal (ekuitas) total yang dimiliki oleh perusahaan atau bisa juga sejauh mana perbandingan kewajiban perusahaan dibandingkan dengan modal sendiri (ekuitas). Debt to equity ratio (DER) berguna bagi investor/calon investor untuk mengetahui apakah utang perusahaan tergolong besar atau wajar. Debt to equity ratio (DER) merupakan bagian dari rasio solvabilitas/ leverage yang digunakan untuk menunjukan seberapa besar kemampuan perusahaan dalam memenuhi kewajibannya, baik kewajiban jangka panjang ataupun jangka pendek. Hasil penelitian oleh Takarini \& Hendrarini (2011) menunjukkan bahwa DER berpengaruh negatif tidak signifikan terhadap harga saham dan ini didukung oleh Yulianti (2014). Hal ini berbeda dengan penelitian yang dilakukan oleh Wulandari (2009), Octaviani \& Komalasari (2017), Susilawati (2012), Safitri (2016), Leksono, et all (2015), Mi (2015), Nuel (2015), yang menyatakan bahwa DER berpengaruh signifikan terhadap harga 
saham. Pranata \& Kurnia (2013) menyatakan bahwa DER tidak memiliki pengaruh negatif signifikan terhadap harga saham.

Net profit margin (NPM) adalah rasio yang digunakan untuk menunjukkan kemampuan perusahaan dalam menghasilkan keuntungan bersih. Semakin besar Net profit margin (NPM) berarti semakin efisien perusahaan tersebut dalam mengeluarkan biaya-biaya sehubungan dengan kegiatan operasinya. Semakin besar Net profit margin (NPM), maka kinerja perusahaan akan semakin produktif, sehingga akan meningkatkan kepercayaan investor untuk menanamkan modalnya pada perusahaan tersebut. Takarini \& Hendrarini (2011) menyatakan bahwa NPM berpengaruh positif tidak signifikan Hal yang sama juga disampaikan oleh Ito \& Dwidjosumarno (2017) dan Nurlia (2016). Akan tetapi Pranata \& Kurnia (2013) menyatakan bahwa NPM mempunyai pengaruh yang signifikan terhadap harga saham

Earning per share (EPS) merupakan komponen penting yang harus diperhatikan dalam analisis perusahaan. Informasi Earning per share (EPS) suatu perusahaan menunjukkan besarnya laba bersih perusahaan yang siap dibagikan untuk semua pemegang saham perusahaan. Earning per share (EPS) merupakan rasio yang menunjukkan berapa besar keuntungan (return) yang diperoleh investor atau pemegang saham per lembar saham. Menurut Husaini (2012), Wulandari (2009), Sasongko dan Wulandari (2006), Putri \& Soekotjo (2017), Sulistiyowati (2012) EPS berpengaruh terhadap harga saham.

Untuk dapat membuktikan teori dan penelitian terdahulu mengenai rasio keuangan diatas, maka judul penelitian yang diambil oleh penulis yaitu : " PENGARUH CURRENT RATIO (CR), DEBT TO EQUITY RATIO (DER) , NET PROFIT MARGIN (NPM) DAN EARNING PER SHARE (EPS) TERHADAP HARGA SAHAM PERUSAHAAN KONSTRUKSI \& BANGUNAN YANG TERDAFTAR DI BURSA EFEK INDONESIA (BEI) PERIODE 2013-2017 ”.

\section{METODOLOGI PENELITIAN}

Variabel yang digunakan dalam penelitian ini dikelompokkan sebagai berikut:

\section{Variabel terikat (dependent variable)}

Variabel terikat dalam penelitian ini adalah harga saham harga saham penutupan (adjusted closing price) dari perusahaan konstruksi dan bangunan yang terdaftar di BEI periode 2013-2017 yang dinyatakan dalam rupiah.

\section{Variabel bebas (independent variable)}

Variabel bebas adalah variabel-variabel yang diduga secara bebas berpengaruh terhadap harga saham perusahaan. Variabel-variabel tersebut adalah :

$\mathrm{X} 1=$ Current ratio $(\mathrm{CR})$

$\mathrm{X} 2$ = Debt to equity ratio $(\mathrm{DER})$

$\mathrm{X} 3=$ Net profit margin $(\mathrm{NPM})$

$\mathrm{X} 4$ = Earning Per Share (EPS)

Pada penelitian ini digunakan jenis penelitian dengan teknik purposive sampling terhadap perusahaan konstruksi dan bangunan periode 2013-2019 dan didapatkan 9 perusahaan yang memenuhi kriteria. Teknik analisa yang digunakan adalah analisa data panel dengan bantuan software Eviews 10, dimana hasil outpur Eviews menujukkan bahwa penggunaan fixed effect model adalah yang terbaik.

\section{E. HASIL PENELITIAN DAN KESIMPULAN}

Berdasarkan dari hasil analisis data yang telah dilakukan mengenai pengaruh CR, DER, NPM dan EPS terhadap harga saham perusahaan konstruksi dan bangunan yang terdaftar di Bursa Efek Indonesia periode 2013-2017 maka dapat diambil kesimpulan sebagai berikut :

Hasil penelitian menunjukkan bahwa Current ratio (CR) tidak berpengaruh signifikan terhadap harga saham bagi perusahaan konstruksi dan bangunan. Koefisien regresi untuk CR adalah sebesar -0.010031 yang artinya CR mempunyai pengaruh negatif terhadap harga saham 
sebesar -0.010031. CR yaitu kemampuan aktiva lancar perusahaan dalam memenuhi kewajiban jangka pendek dengan aktiva lancar yang dimiliki. Semakin tinggi CR berarti semakin besar kemampuan perusahaan untuk membayar kewajiban jangka pendek. CR merupakan rasio likuiditas dimana para kreditor mengukur operasi perusahaan dengan melihat apakah aktiva lancer perusahaan dapat memenuhi kewajiban jangka pendeknya saat kewajiban jangka pendek ini segera ditagih atau saat jatuh tempo. Karena semakin tinggi CR maka semakin besar kemampuan perusahaan dalam melunasi hutang-hutangnya. Maka para kreditor dapat mempertimbangkan untuk memberikan pinjaman bagi perusahaan, tapi untuk para investor CR tidak memiliki pengaruh dikarenakan investor hanya melihat pada kegiatan usaha perusahaan tanpa melihat likuiditas perusahaan. Sehingga dari penelitian ini menunjukan bahwa variabel CR tidak digunakan oleh para investor sebagai pertimbangan dalam berinvestasi pada suatu perusahaan. Hal ini sejalan dengan hasil penelitian yang disampaikan oleh Susilawati (2012), Mi (2015), Nuel (2015), Octaviani \& Komalasari (2017), Nurlela (2017).

Hasil yang sama juga ditunjukkan oleh Debt to equity ratio (DER) yang dimana dalam penelitian ini tidak memiliki pengaruh yang signifikan terhadap harga saham bagi perusahan konstruksi dan bangunan. Debt to equity ratio (DER). Koefisien regresi untuk Debt to equity ratio (DER) adalah sebesar -0.019925 . DER sebagai salah satu rasio keuangan dapat menjadi tolak ukur kinerja keuangan diantaranya mengukur tingkat penggunaan utang terhadap total shareholder's equity yang dimiliki perusahaan, DER berpengaruh negative terhadap pertumbuhan laba, serta DER berpengaruh pada dividen. DER memiliki pengaruh negatif terhadap Dividend Payout Ratio (DPR). DER yang tinggi menandakan bahwa kebutuhan ekuitas sebagian besar dipenuhi dari hutang. Hal ini sejalan dengan hasil penelitian yang disampaikan oleh Takarini \& Hendrarini (2011) dan Putri \& Soekotjo (2017).

Variabel Net profit margin (NPM) berdasarkan hasil penelitian ini dikatakan memiliki pengaruh yang signifikan terhadap harga saham perusahaan konstruksi dan bangunan. Koefisien regresi yang bernilai -0.757760 , menunjukkan bahwa NPM memberikan pengaruh negatif yang signifikan terhadap harga saham. NPM terdiri dari 2 unsur yakni laba bersih setelah pajak serta pendapatan atau penjualan bersih. NPM memiliki pengaruh yang negatif dan signifikan. Hal ini dapat diakibatkan oleh unsur dasar dari NPM itu sendiri, di mana investor biasanya akan lebih memperhatikan angka penjualan bersih atau omzet dari perusahaan pada saat akan mengambil keputusan untuk berinvestasi. Meningkatnya penjualan yang tidak diikuti meningkatnya laba bersih dapat menurunkan persentasi NPM. Laba bersih sendiri dipengaruhi oleh beban serta biaya yang pada kenyataannya terus mengalami peningkatan. Hal ini sejalan dengan hasil penelitian yang disampaikan oleh Egam, et all (2017).

Pengaruh Earning per share (EPS) terhadap harga saham dikatakan signifikan dalam penelitian ini dan memiliki koefisien regresi yang bernilai 0.000964, EPS menggambarkan profitabilitas perusahaan yang secara langsung tergambar secara langsung pada setiap lembar saham. EPS memiliki pengaruh yang positif. Semakin tinggi EPS maka semakin tinggi minat investor untuk berinvestasi dikarenakan makin besar laba yang didapatkan oleh pemegang saham serta kemungkinan peningkatan jumlah dividen. Hal ini sejalan dengan hasil penelitian yang disampaikan oleh Egam, et all (2017).

Secara bersama-sama terdapat pengaruh yang signifikan antara Current ratio $(\mathrm{QR})$, Debt to equity ratio (DER), Net profit margin (NPM) dan Earning per share (EPS) yang artinya secara bersama-sama variabel CR, DER, NPM dan EPS berpengaruh secara signifikan terhadap variabel harga saham atau model regresi yang dibuat adalah signifikan pada tingkat kepercayaan 5\%. Hasil output regresi menunjukkan bahwa nilai adjusted r-square 0.943930 yang artinya secara bersama-sama variabel CR, DER, NPM dan EPS mempunyai kontribusi menjelaskan harga saham sebesar $92.29 \%$, sisanya sebesar $7.71 \%$ dijelakan oleh variabel lain yang tidak diteliti atau tidak dimasukkan dalam model penelitian ini. 


\section{F. DAFTAR PUSTAKA}

Amanah, Raghilia et al. (2014). Pengaruh Rasio Likuiditas Dan Rasio Profitabilitas Terhadap Harga Saham. Jurnal Administrasi Bisnis, 12 (1), 1-10

Brealy, Richard A., Myers, Steward C., \& Marcus, Alan J. (2007). Dasar-Dasar Manajemen Keuangan Perusahaan. Jakarta: Penerbit Erlangga.

Fabbozi, Frank J. (1999). Manajemen Investasi. Jakarta: Penerbit Salemba Empat.

Harga saham adjusted price dari https://finance.yahoo.com/

Husaini, Ahmad. (2012). Pengaruh Variabel Return On Asset, Return On Equity, Net profit margin dan Earning per share Terhadap Harga Saham Perusahaan. Jurnal Profit, 6(1), 45-49.

Ito, Novendri Alfin \& Dwijosumarno, Bambang Hadi Santoso. (2017), Jurnal Ilmu dan Riset Manajemen, 6(1),1-21.

Jufrizen. (2012). Pengaruh Rasio Profitabilitas Terhadap Harga Saham pada Perusahaan yang Tercatat dalam LQ45 di Bursa Efek Indonesia. Jurnal Visioner \& Strategis, 1(2),197211.

Keown, Arthur J., Martin, John D., \& Petty, J. William., Scott, David J. (2011). Manajemen Keuangan $\left(10^{\text {th }}\right.$ ed). Jakarta: PT Indeks.

Laporan Keuangan dari www.idx.co.id

List Perusahaan Bangunan dari https://www.sahamok.com/emiten/sektor-property-realestate/sub-sektor-konstruksi-bangunan/

Leksono, Andiko et al. (2015). Pengaruh Rasio Likuiditas, Profitabilitas, dan Solvabilitas Terhadap Harga Saham Perusahaan Perbankan di BEI Periode 2009-2013. Jurnal Akuntansi UBHARA, 12-22.

Mi, Mujairi. (2015). Pengaruh Rasio Keuangan Terhadap Harga Saham Pada Perusahaan Otomotif yang Terdaftar di Bursa Efek Indonesia. Jurnal Pemikiran Penelitian Ekonomi (Wacana Equilibrium), 4(1), 1-12.

Nuel, Yohanis. (2015). Pengaruh Rasio Likuiditas, Solvabilitas dan Profitabilitas Terhadap Harga Saham Perusahaan Sub Sektor Perkebunan Kelapa Sawit di Bursa Efek Indonesia. Jurnal Administrasi Bisnis, 3(4), 806-820.

Nurlela. (2017). Analisis Pengaruh Rasio Likuiditas, Leverage dan Profitabilitas Terhadap Harga Saham (Studi Perusahaan Subsektor Farmasi Di Bursa Efek Indonesia Periode 2011-2015). Jurnal Administrasi Bisnis, 5(2), 466-480.

Nurlia. (2016). Pengaruh Rasio Profitabilitas Terhadap Harga Saham Pada Perusahaan Rokok Yang Terdaftar di Bursa Efek Indonesia. Jurnal Sains Terapan, 1(2), 60-66.

Octaviani, Santi \& Komalasari, Dahlia. (2017). Pengaruh Likuiditas, Profitabilitas, dan Solvabilitas Terhadap Harga Saham (Studi Kasus Pada Perusahaan Perbankan Yang Terdaftar di Bursa Efek Indonesia). Jurnal Akuntansi, 3(2), 77-89.

Pranata, Hans Christian \& Kurnia, Ratnawati. (2013). Pengaruh Profitabilitas, Likuiditas, Solvabilitas, dan Kebijakan Dividen Terhadap Harga Saham (Studi pada perusahaan go public yang terdaftar dalam indeks Kompas100 periode 2009-2011). Jurnal Ultima Accounting, 5(2),81-98.

Putri, Eka Oktaviani \& Soekotjo, Hendri. (2017). Pengaruh Rasio Profitabilitas, Likuiditas dan Solvabilitas Terhadap Harga Saham Perusahaan Manufaktur yang terdaftar di Bursa Efek Indonesia tahun 2011-2015. Jurnal Ilmu dan Riset Manajemen, 6(7), 1-19.

Safitri. (2016). Pengaruh PER, ROA, DAN DER Terhadap Harga Saham Pada Perusahaan Sub Sektor Lembaga Pembiayaan di Bursa Efek Indonesia. Jurnal Administrasi Bisnis, 4(2), 535-549.

Sardiyati. (2016). Pengaruh Kinerja Keuangan Terhadap Harga Saham Perusahaan Sub Sektor Makanan dan Minuman di Bursa Efek Indonesia. Jurnal Administrasi Bisnis, 4(3), 642656. 
Sasongko, Noer \& Wulandari, Nila. (2006). Pengaruh EVA dan Rasio-Rasio Profitabilitas Terhadap Harga Saham. Jurnal Empirika, 19(1),64-80.

Sulistyowati, Yayuk. (2012). Pengaruh Earning per share (EPS), Price Earning Ratio (PER) dan Dividend Payout Ratio (DPR) terhadap harga saham (Studi Empiris Pada Perusahaan Food \& Beverages Yang Terdaftar di BEI). Jurnal Modernisasi, 8(3), 247-255.

Susilawati, Christine Dwi Karya. (2012). Analis Perbandingan Pengaruh Likuiditas, Solvabilitas, dan Profitabilitas Terhadap Harga Saham Pada Perusahaan LQ 45. Jurnal Akuntansi, 4(2), 165-174.

Takarini, Nurjanti \& Hendrarini, Hamidah. (2011). Rasio Keuangan dan Pengaruhnya Terhadap Harga Saham Perusahaan Yang Terdaftar Di Jakarta Islamic Index. Journal of Business and Banking, 1(2), 93-104.

Widarjono, Agus. (2016). Ekonometrika Pengantar dan Aplikasinya (4 ${ }^{\text {th }}$ ed). Yogyakarta: UPP STIM YKPM.

Widoatmodjo, Sawidji. (2005). Cara Sehat Investasi di Pasar Modal (Pengantar Menjadi Investor Profesional). Jakarta: Elex Media Komputindo.

Wulandari, Dhita Ayudia. Analisis Faktor Fundamental Terhadap Harga Saham Industri Pertambangan dan Pertanian di BEI. Jurnal Akuntansi dan Keuangan, 1-13.

Yulianti, Eka. (2014). Pengaruh Solvabilitas, dan Profitabilitas Terhadap Harga Saham Perusahaan-Perusahaan Perbankan Pada Saham Kelompok Indeks LQ-45 di Bursa Efek Indonesia. Jurnal Portofolio, 11(1), 1-9. 